\title{
Effect of glycerol and dihydroxyacetone concentrations in the culture medium on the growth of acetic acid bacteria Gluconobacter oxydans ATCC 621
}

\author{
Lidia Stasiak-Różańska • Stanisław Błażejak • \\ Iwona Gientka
}

Received: 16 December 2013 / Revised: 17 April 2014 / Accepted: 28 April 2014 / Published online: 20 May 2014

(C) The Author(s) 2014. This article is published with open access at Springerlink.com

\begin{abstract}
Bacteria of the species Gluconobacter oxydans are applied in the industrial production of dihydroxyacetone (DHA) via glycerol oxidation. The major problem of this biotransformation involves process inhibition by substrate and/or product. Improper initial concentration of glycerol and increasing DHA concentration may inhibit the metabolic activity of bacterial cells and impede further course of the reaction. An attempt was, therefore, undertaken in this study to determine which concentrations of glycerol $\left(30,50,70,100 \mathrm{~g} \mathrm{~L}^{-1}\right)$ and DHA $\left(10-100 \mathrm{~g} \mathrm{~L}^{-1}\right)$ may inhibit the growth of acetic acid bacteria of $G$. oxydans ATCC 621 species. Cultures of this strain were run in the Bioscreen C MBR apparatus on experimental culture media with various initial concentrations of glycerol and DHA. Analyses were also carried out to examine the impact of $\mathrm{pH}(5.0,7.0,8.0)$ of glycerol-containing culture media on cell growth of the analyzed strain $G$. oxydans. None of the applied substrate concentrations was inhibiting cellular divisions of $G$. oxydans bacteria. The initial glycerol concentrations that enabled rapid cellular divisions reached $50 \mathrm{~g} \mathrm{~L}^{-1}$ in the medium with $\mathrm{pH} 5.0$ (coefficient of specific growth rate $\mu=0.0550$ ) and $70 \mathrm{~g} \mathrm{~L}^{-1}$ in the medium with $\mathrm{pH} 7.0(\mu=0.0556)$. DHA was shown to inhibit the mitotic activity of $G$. oxydans bacteria even at low concentrations (20-30 g L $\left.{ }^{-1}\right)$, whereas at the concentration of $70 \mathrm{~g} \mathrm{~L}^{-1}$, it made cell divisions impossible. The applied $\mathrm{pH}$ values of the culture media did not inhibit the growth of G. oxydans strain.
\end{abstract}

L. Stasiak-Różańska $(\bowtie) \cdot$ S. Błażejak · I. Gientka Department of Biotechnology, Microbiology and Food Evaluation, Warsaw University of Life Sciences - SGGW, Nowoursynowska St. 159 c, Warsaw, Poland e-mail: lidia_stasiak@sggw.pl
Keywords Gluconobacter oxydans · Glycerol · Dihydroxyacetone $\cdot$ Inhibition

\section{Introductory remarks}

In the global industry, acetic acid bacteria of the Gluconobacter oxydans species are applied for, among other things, the production of dihydroxyacetone (DHA) via glycerol biotransformation [9, 24].

Dihydroxyacetone (DHA) is a ketotriose used in the food industry as a sweetener in products for diabetic patients [26] and as a dietary supplement for sportsmen [26, 33]. DHA has also been applied in cosmetology (active ingredient of tanning lotions), pharmacy (intermediate compound in drugs production), and medicine (treatment of vitiligo, antidote to cyanide-induced intoxications, component of hemorrhage arresting biomaterials) $[8,13,14,17,30]$.

In $G$. oxydans cells, glycerol biotransformation to DHA is catalyzed by glycerol dehydrogenase (GlyDH, EC 1.1.99.22) that is bound with the cytoplasmic membrane. The reaction proceeds in the periplasmic space of Gramnegative cells of acetic acid bacteria in a $\mathrm{pH}$ range of 5.0 5.5 and is independent of the presence of ATP and NAD $[12,25,29]$.

During microbiological synthesis of DHA, the retardation or arrestment of cellular division of G. oxydans bacteria is likely to occur, which constitutes the major drawback of this method [23]. Proliferation of acetic acid bacteria may as well be inhibited by stress induced by inappropriately selected initial concentration of glycerol (over $50 \mathrm{~g} \mathrm{~L}^{-1}$ ) and/or increasing concentration of DHA (60$\left.80 \mathrm{~g} \mathrm{~L}^{-1}\right)[16,23,26,32,36]$. The cellular mechanisms as well as concentration of glycerol and DHA responsible for this inhibition have not been explicitly identified yet [16]. 
In the past, scientists tried to develop methods that would enable abolishing the undesirable inhibitory effect [5]. So far, studies have mainly been focused on the determination of the optimal composition and $\mathrm{pH}$ of the culture medium [38], process conditions, and degree of reaction medium aeration $[18,35,36]$.

In recent years, some works have appeared [13, 15, 20, 22] that addressed glycerol biotransformation to DHA by genetically modified strains of $G$. oxydans. The modifications consisted in, among other things, designing strains capable of GlyDH overproduction, which ensured higher (compared to parental strain) concentrations of the product. However, the effect of inhibition still occurred (though it was lesser compared to the wild strain) and was disturbing the course of biotransformation.

Contemporarily, DHA is produced exclusively with the biotechnological method using free cells of G. oxydnans. In the industrial production of DHA via glycerol biotransformation by G. oxydans, product's concentration in the reaction medium needs to be continuously monitored and kept at a level below $50 \mathrm{~g} \mathrm{~L}^{-1}$. Biotransformation is run in bioreactors with continuous feeding of the glycerol-containing medium and continuous reception of the post-reaction mixture with DHA [16].

The global demand for DHA is successively increasing, and its new application possibilities are still emerging $[10,17,19,37]$. It seems advisable, therefore, to search for novel solutions to attenuate or eliminate the problem of inhibition accompanying glycerol biotransformation to DHA. One of such solutions may be the determination of doses of glycerol and DHA in the reaction medium that would inhibit the metabolic activity of G. oxydans cells.

The aim of this study was to determine the concentrations of glycerol and DHA that inhibit mitotic divisions of acetic acid bacteria $G$. oxydans ATCC 621 . The effect of $\mathrm{pH}$ value of culture medium on the growth of this strain cells was examined as well.

\section{Materials and methods}

Strain and culture conditions

Experiments were conducted with $G$. oxydans ATCC 621 strain of acetic acid bacteria, originating from the American Type Culture Collection, University of Boulevard, Manassas, United States. The strain was inoculated every 30 days onto slant medium containing $\left(\mathrm{g} \mathrm{L}^{-1}\right)$ yeast extract 5 (Avantor ${ }^{\mathrm{TM}}$ Performance Materials), peptone 3 (Avantor ${ }^{\mathrm{TM}}$ Performance Materials), mannitol 25 (Avantor $^{\mathrm{TM}}$ Performance Materials), and agar 15 (Avantor ${ }^{\mathrm{TM}}$ Performance Materials). For biomass proliferation, a pure culture of $G$. oxydans was transferred into the inoculating culture medium containing $\left(\mathrm{g} \mathrm{L}^{-1}\right)$ yeast extract 30 and ethyl alcohol 20 and having $\mathrm{pH}$ 5.0. The culture was incubated at $28{ }^{\circ} \mathrm{C}$ for $24 \mathrm{~h}$ (to obtain $\mathrm{OD}_{600 \mathrm{~nm}}$ about 0.7 corresponding to $0.5 \mathrm{~g}$ of wet biomass) on a reciprocating shaker (200 cyclesmin $^{-1}$, Edmund Büchler SM-30 Control).

Strain cultures were run in Bioscreen C MBR apparatus in control and experimental culture media. The Bioscreen C MBR apparatus (Oy Growth Curves Ab Ltd. Helsinki, Finland) is designed for microbiological tests that are based on the measurement of optical density (OD) of a liquid medium during the culture of microorganisms. It enables simultaneous running and monitoring of 200 microcultures, placed in incubation cassettes with a volume of $0.4 \mathrm{~cm}^{3}$ in a temperature range of $1-60{ }^{\circ} \mathrm{C}$.

The experiment was carried out in culture media with active acidity of 5.0 that is optimal for the metabolic activity of most species of acetic acid bacteria [31]. Analyses were also conducted for culture medium with $\mathrm{pH} 7.0$ that ensured a high activity of GlyDH and for culture medium with $\mathrm{pH} 8.0$ that stabilized this enzyme $[1,25]$.

The study investigated various concentrations of glycerol $\left(30,50,70\right.$, or $\left.100 \mathrm{~g} \mathrm{~L}^{-1}\right)$ and DHA $(10,20,30,40$, $50,55,60,65,70,75,80,85,90,95$, or $\left.100 \mathrm{~g} \mathrm{~L}^{-1}\right)$ on the growth of $G$. oxydans.

The control medium contained only $\left(\mathrm{g} \mathrm{L}^{-1}\right)$ yeast extract 30 and ethyl alcohol 20 (pH 5.0).

\section{All media were sterilized at $121{ }^{\circ} \mathrm{C}$ for 20 minutes}

Sterile control and experimental media were inoculated with $1 \% \mathrm{v} / \mathrm{v}$ strain of $G$. oxydans bacteria originating from a 24-h inoculating culture. Shaken culture was run at a temperature of $28{ }^{\circ} \mathrm{C}$, for $180 \mathrm{~h}$. According to the producer's recommendations, a broadband filter $(\lambda=420-580 \mathrm{~nm})$ was selected for OD measurements. The OD of the culture was measured every hour. Strain cultures in a selected medium were carried out in three parallel replications.

\section{Experimental dates}

Experimental dates were analyzed based on the plots of a correlation between culture OD and culture duration, made in Excel sheet. The coefficient of specific growth rate $(\mu)$ in time $(t)$ was calculated from the formula: $\mu(t)=(\ln$ $\left.\mathrm{OD}_{\mathrm{f}}-\ln \mathrm{OD}_{\mathrm{i}}\right) /\left(t_{\mathrm{f}}-t_{\mathrm{i}}\right)$, where $\mathrm{OD}_{\mathrm{f}}$-final OD in the $\log$ phase, $\mathrm{OD}_{\mathrm{i}}$-initial OD in the $\log$ phase, $t_{\mathrm{f}}$-time of $\log$ phase termination, and $t_{\mathrm{i}}$ - time of log-phase onset [39].

Statistical analysis

Statistical analysis was made for more than 22700 obtained results. Standard deviation ranged between 0.002-0.017. 


\section{Results and discussion}

Effect of active acidity and glycerol concentration on the growth of G. oxydans ATCC 621 bacteria

The OD values obtained in the experiment allowed calculating the coefficient of the specific growth rate of G. oxydans cells $(\mu)$ and determining the length of the adaptation phase (lag) and intensive divisions phase (log). Respective results were presented in Table 1.

Figure 1 presents curves of a correlation between OD of $G$. oxydans culture in control and experimental media at pH 5.0 and diversified concentrations of glycerol.

Optical density (OD) measurements of G. oxydans culture run in the control medium (without glycerol) at $\mathrm{pH} 5.0$ indicate a short 5-h phase of cells adaptation to the proposed environmental conditions (Table 1). In the control medium, the logarithmic phase lasted $10 \mathrm{~h}$ and the highest OD value reached 0.385 (Table 1). The coefficient of specific growth rate reached 0.0618 , and its value (compared to other $\mu$ values presented in Table 1) showed the capability of $G$. oxydans strains for rapid cellular divisions in the proposed conditions.

The course of the growth curves of G. oxydans bacteria in the culture media with $\mathrm{pH} 5.0$ and increasing concentrations of glycerol 30,50 , or $70 \mathrm{~g} \mathrm{~L}^{-1}$ was initially similar (Fig. 1). The logarithmic phase spanned from 10 to $15 \mathrm{~h}$ (Fig. 1). Within the next $20 \mathrm{~h}$, differences were observed in the OD of these culture. After $50 \mathrm{~h}$ of culture run at $\mathrm{pH}$ 5.0, the OD of culture media with glycerol concentration of 30 or $50 \mathrm{~g} \mathrm{~L}^{-1}$ reached ca. 0.3 and did not change till the end of the experiment (Fig. 1).

In the culture medium with $\mathrm{pH} 5.0$ and the lowest applied glycerol concentration $\left(30 \mathrm{~g} \mathrm{~L}^{-1}\right)$, the rate of
Table 1 Effect of glycerol addition in the experimental media on the coefficient of specific growth rate $(\mu)$, length of lag phase, length of log phase, and the highest value of OD
Fig. 1 Changes in the optical density of $G$. oxydans cells culture in control and experimental media with the addition of glycerol $\left(30,50,70,100 \mathrm{~g} \mathrm{~L}^{-1}\right)$, pH 5.0

\begin{tabular}{|c|c|c|c|c|c|c|}
\hline & & $\mu\left(\mathrm{h}^{-1}\right)$ & $\begin{array}{l}\text { Length of lag } \\
\text { phase (h) }\end{array}$ & $\begin{array}{l}\text { Length of log } \\
\text { phase (h) }\end{array}$ & $\begin{array}{l}\text { Initial OD in log } \\
\text { phase }\end{array}$ & $\begin{array}{l}\text { Final OD in } \\
\text { log phase }\end{array}$ \\
\hline \multicolumn{2}{|c|}{ Control medium, pH 5.0} & 0.0618 & 5 & 10 & 0.208 & 0.385 \\
\hline $\mathrm{pH}$ & $\begin{array}{l}\text { Glycerol conc. } \\
\left(\mathrm{g} \mathrm{L}^{-1}\right)\end{array}$ & & & & & \\
\hline \multirow[t]{4}{*}{5.0} & 30 & 0.0373 & 10 & 10 & 0.208 & 0.320 \\
\hline & 50 & 0.0550 & 10 & 10 & 0.199 & 0.345 \\
\hline & 70 & 0.0450 & 10 & 15 & 0.190 & 0.373 \\
\hline & 100 & 0.0391 & 15 & 20 & 0.187 & 0.409 \\
\hline \multirow[t]{4}{*}{7.0} & 30 & 0.0379 & 5 & 15 & 0.191 & 0.337 \\
\hline & 50 & 0.0451 & 8 & 12 & 0.193 & 0.303 \\
\hline & 70 & 0.0566 & 8 & 14 & 0.185 & 0.365 \\
\hline & 100 & 0.0357 & 10 & 19 & 0.180 & 0.355 \\
\hline \multirow[t]{4}{*}{8.0} & 30 & 0.0467 & 4 & 11 & 0.177 & 0.296 \\
\hline & 50 & 0.0520 & 7 & 10 & 0.182 & 0.306 \\
\hline & 70 & 0.0443 & 13 & 12 & 0.188 & 0.320 \\
\hline & 100 & 0.0143 & 7 & 43 & 0.179 & 0.331 \\
\hline
\end{tabular}

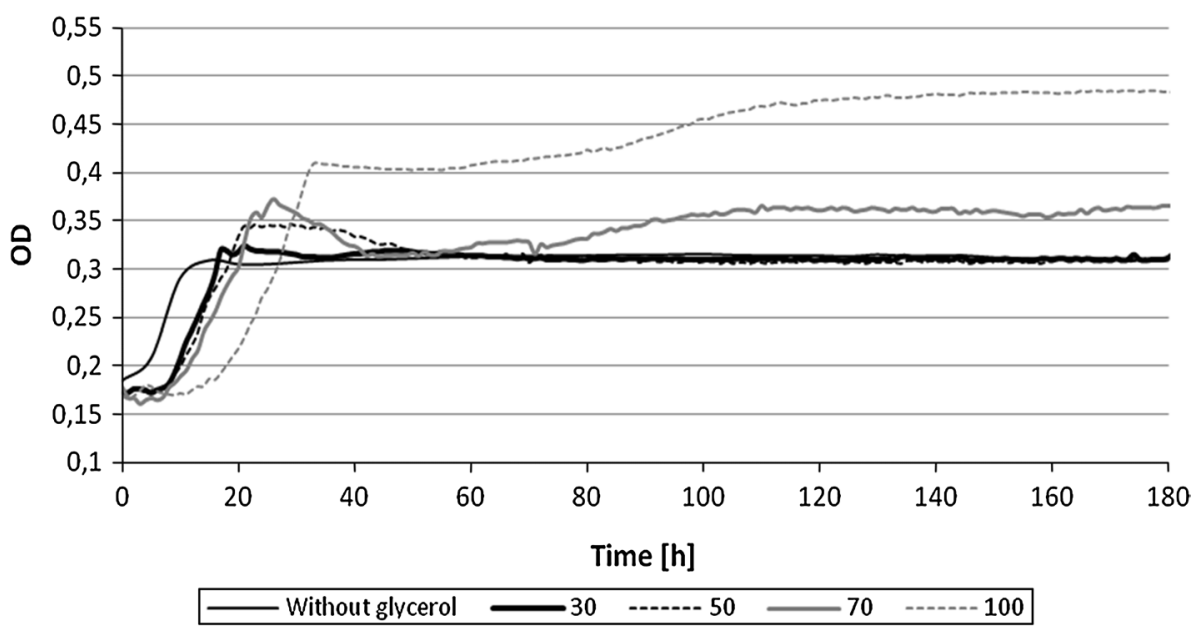


Fig. 2 Changes in the optical density of G. oxydans cells culture in the experimental culture media with the addition of glycerol $\left(30,50,70,100 \mathrm{~g} \mathrm{~L}^{-1}\right)$, pH 7.0

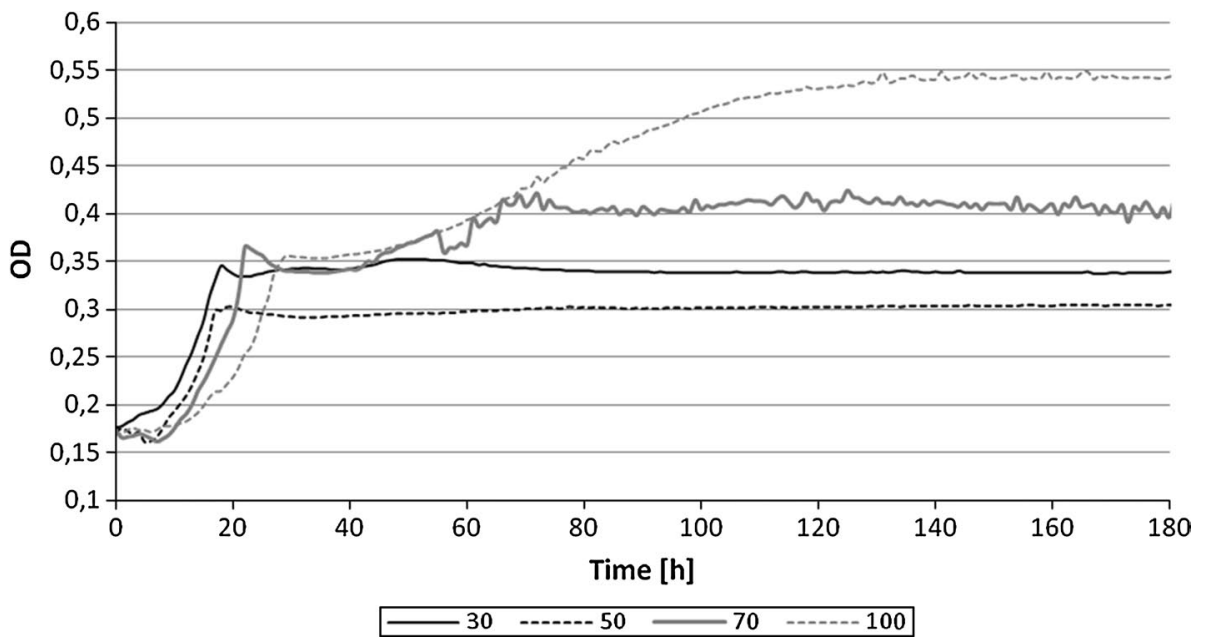

G. oxydans cells growth was the lowest, which was indicated by the lowest value of $\mu$ coefficient $(\mu=0.0373)$ in this variant of culture. Probably, the low dose of glycerol $\left(30 \mathrm{~g} \mathrm{~L}^{-1}\right)$ in the medium and its active acidity of $\mathrm{pH} 5.0$ directed the metabolism of $G$. oxydans bacteria toward the activation of glycerol dehydrogenase and not toward biomass production [12, 16, 25, 26]. Glycerol applied in a dose of $50 \mathrm{~g} \mathrm{~L}^{-1}$ initiated cellular division after $10 \mathrm{~h}$ of culture incubation, and in this variant, the coefficient of specific growth rate reached $\mu=0.0550$ and was the highest for all cultures run in culture media with $\mathrm{pH}$ 5.0. These observations confirmed earlier literature data [23, 26, 38], according to which glycerol concentration in the medium being optimal for the growth of acetic acid bacteria at $\mathrm{pH}$ 5.0 should reach $50 \mathrm{~g} \mathrm{~L}^{-1}$. A successive increase in substrate content ( 70 or $100 \mathrm{~g} \mathrm{~L}^{-1}$ ) in the medium with $\mathrm{pH} 5.0$ caused a decrease in the value of $\mu$ coefficient compared to the medium fortified with glycerol at $50 \mathrm{~g} \mathrm{~L}^{-1}$. The applied higher concentrations of the substrate (70 and $100 \mathrm{~g} \mathrm{~L}^{-1}$ ) probably had a negative impact on the metabolic activity of the analyzed bacteria and enforced longer adaptation (10$15 \mathrm{~h}$ ) of cells to environmental conditions (Table 1).

In the culture medium with $\mathrm{pH} 5.0$ and glycerol concentration of $100 \mathrm{~g} \mathrm{~L}^{-1}$, a tangible increase in the OD value occurred between the 60th and 120th hour of the culture $(\mathrm{OD}=0.400$ and 0.480 , respectively, Fig. 1). Most likely, part of glycerol was earlier oxidized to DHA, which constituted an easily available source of carbon to G. oxydans bacteria and could be utilized for biomass growth [34].

Earlier investigations $[23,26]$ have shown that glycerol content in the production medium deemed indispensable for the proper course of glycerol biotransformation to DHA should fit within the range of $20-50 \mathrm{~g} \mathrm{~L}^{-1}$. Its higher concentration may lead to the deterioration of acetic acid bacteria growth as a result of hyperosomotic stress as well as to reduced reaction yield. As reported by Mishra et al. [25] and
Claret et al. [6], at the initial glycerol content in the medium reaching $90-120 \mathrm{~g} \mathrm{~L}^{-1}$, the cellular divisions of acetic acid bacteria were disturbed and DHA synthesis was impossible. The increasing initial concentration of substrate was accompanied by elongating time of reaction that enabled achieving a high concentration of the reaction product $[6,25]$.

The above results indicate the feasibility of $G$. oxydans growth at active acidity of 5.0 and applied doses of glycerol (30, 50, 70, and $\left.100 \mathrm{~g} \mathrm{~L}^{-1}\right)$. Simultaneously, the increasing concentration of the substrate in the range of $50-100 \mathrm{~g} \mathrm{~L}^{-1}$ resulted in elongation of the adaptation and logarithmic phases of $G$. oxydans strain. This information may be useful in the formulation of culture medium composition for glycerol biotransformation into DHA.

The next stage of the study included the determination of the impact of various glycerol concentrations in culture media with $\mathrm{pH} 7.0$ on the growth of G. oxydans. The active acidity of 7.0 was optimal for the activity of glycerol dehydrogenase that catalyzes glycerol biotransformation to DHA [6, 40]. Our earlier investigations [34] demonstrated the feasibility of running the biotransformation not only at $\mathrm{pH}$ optimal for G. oxydans growth (pH 5.0), but also at $\mathrm{pH}$ optimal for GlyDH activity ( $\mathrm{pH}$ 7.0). However, at the active acidity of 7.0, the yield of the process depends also on the concentrations of the substrate and the product.

The course of G. oxydans ATCC 621 growth in the culture medium with $\mathrm{pH} 7.0$ and initial glycerol concentration at $30 \mathrm{~g} \mathrm{~L}^{-1}$ (Fig. 2) was similar to the growth of this strain in the medium with the same glycerol content but at $\mathrm{pH} 5.0$ (Fig. 1). After $20 \mathrm{~h}$, the OD of the culture in the medium with pH 7.0 (glycerol $30 \mathrm{~g} \mathrm{~L}^{-1}$ ) was at ca. 0.34 (Fig. 2), whereas in the medium with $\mathrm{pH} 5.0$, its value reached ca. 0.32 (Fig. 1). These results suggest that the applied $\mathrm{pH}$ values (5.0 or 7.0) had no significant effect on the growth of $G$. oxydans bacteria in the culture media with the lowest substrate addition $\left(30 \mathrm{~g} \mathrm{~L}^{-1}\right)$. 
Fig. 3 Changes in the optical density of $G$. oxydans cells culture in the experimental media with the addition of glycerol $\left(30,50,70,100 \mathrm{~g} \mathrm{~L}^{-1}\right), \mathrm{pH} 8.0$

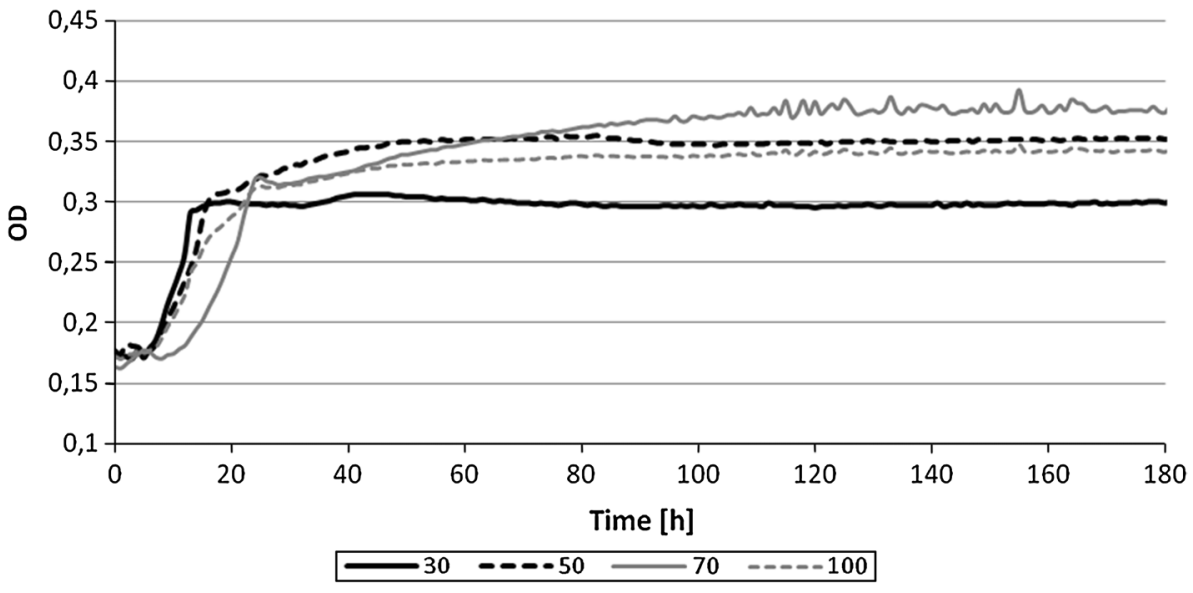

Experimental variants with $\mathrm{pH} 5.0$ or $\mathrm{pH} 7.0$ and glycerol concentration $50 \mathrm{~g} \mathrm{~L}^{-1}$ (Figs. 1,2) were characterized by a short phase of cells adaptation to environmental conditions (up to $10 \mathrm{~h}$ ) and by short logarithmic growth phase (another $10 \mathrm{~h}$ ). The stationary phase began after $20 \mathrm{~h}$ of culture incubation. In that period, the OD value was at ca. 0.345 in the medium with $\mathrm{pH} 5.0$ and glycerol concentration of $50 \mathrm{~g} \mathrm{~L}^{-1}$ and at 0.303 in the medium with $\mathrm{pH} 7.0$ and the same addition of glycerol (Figs. 1,2).

Cells of $G$. oxydans bacteria placed in the medium with glycerol concentration of $70 \mathrm{~g} \mathrm{~L}^{-1}$ and $\mathrm{pH} 7.0$ needed ca. $8 \mathrm{~h}$ to adapt to new environmental conditions. Afterward, a rapid increase was observed in the rate of cellular divisions, which was indicated by an increase in OD value from 0.18 after ca. $15 \mathrm{~h}$ of culture to 0.365 after ca. $20 \mathrm{~h}$ (Fig. 2).

The measurements of OD of G. oxydans culture in the medium with $\mathrm{pH} 7.0$ and the highest initial concentration of glycerol $\left(100 \mathrm{~g} \mathrm{~L}^{-1}\right)$ demonstrate a two-stage logarithmic phase (likewise in the medium with $\mathrm{pH} 5.0$ and glycerol content at $100 \mathrm{~g} \mathrm{~L}^{-1}$, Fig. 1). Between the 15 th and the 35 th hour of culture, the OD of the suspension increased significantly (from $\mathrm{OD}=0.2$ to 0.355 , respectively); between the 35th and 50th hour, no significant changes were observed in OD values, whereas after $50 \mathrm{~h}$ the OD was successively increasing to reach the value of 0.540 after the 130th hour (Fig. 2).

Incubation of $G$. oxydans cultures in the experimental media with $\mathrm{pH} 7.0$ and various initial concentrations of glycerol $\left(30,50,70,100 \mathrm{~g} \mathrm{~L}^{-1}\right)$ enabled shortening the adaptation phase, compared to the cultures run on the same media but at $\mathrm{pH}$ optimal for the growth of acetic acid bacteria ( $\mathrm{pH}$ 5.0), Table 1.

The coefficient of the specific growth rate noted for $G$. oxydans cells cultured in the medium with $\mathrm{pH} 7.0$ and glycerol concentration at $70 \mathrm{~g} \mathrm{~L}^{-1}$ reached 0.0566 and was the highest in this experimental variant (Table 1). The active acidity of 7.0 was not optimal for the metabolic activity of $G$. oxydans cells, although the results achieved clearly showed that the growth of these bacteria was similar to growth observed at $\mathrm{pH} 5.0$ and the same glycerol doses (Table 1). Interestingly, at $\mathrm{pH} 7.0$, the bacterial cells were more quickly adapting to environmental conditions (shorter lag phase) than at $\mathrm{pH} 5.0$ (Table 1). The highest value of the specific growth rate $\mu$ in the medium with $\mathrm{pH} 7.0$ was determined for the cells cultured in the medium with glycerol dose of $70 \mathrm{~g} \mathrm{~L}^{-1}(\mu=0.0566)$, Table 1 .

Another stage of the study addressed the impact of various concentrations of glycerol on the growth of $G$. oxydans in culture media with $\mathrm{pH} 8.0$ (Fig. 3). The applied active acidity was stabilizing glycerol dehydrogenase $[1,2,21]$. At $\mathrm{pH}$ value in the range of 8.0-10.0 and in the presence of glycerol, cytoplasmic pathway is activated in cells of acetic acid bacteria that leads to the growth of cellular biomass $[3,7]$.

Cells of G. oxydans cultured in the medium with $\mathrm{pH} 8.0$ and the lowest initial concentration of glycerol $\left(30 \mathrm{~g} \mathrm{~L}^{-1}\right)$ reached the stationary phase after $15 \mathrm{~h}$ and ever since the OD of the culture was remaining at ca. 0.3 till the end of the experiment (Fig. 3). Changes in the OD of cultures incubated in the medium with $\mathrm{pH} 8.0$ and glycerol concentration of 50 or $100 \mathrm{~g} \mathrm{~L}^{-1}$ were similar throughout the experimental period (Fig. 3). For these cultures, the phase of bacterial cells adaptation to medium conditions lasted $7 \mathrm{~h}$. In the stationary phase, the OD of these cultures was at the level of 0.35 (Fig. 3). Literature data [2, 3, 7] demonstrate that at $\mathrm{pH} 8.5$, glycerol is consumed for the growth of acetic acid bacteria biomass.

No intensive growth of $G$. oxydans cells was observed in the culture media with $\mathrm{pH} 8.0$ and various initial concentrations of glycerol compared to strains grown at $\mathrm{pH} 5.0$ or 7.0 and the same concentrations of glycerol (Figs. 1, 2, 3). In contrast, at the highest active acidity of the medium $(\mathrm{pH}$ 8.0, Fig. 3), the OD of G. oxydans cultures run at the initial glycerol doses of 70 or $100 \mathrm{~g} \mathrm{~L}^{-1}$, attained the lowest values ( 0.320 and 0.331 on average) compared to the OD of cultures grown at pH $5.0(0.373,0.409)$ or $\mathrm{pH} 7.0(0.365,0.355)$ and the same initial concentration of glycerol (Table 1). 
Results achieved in the study enable concluding that the highest coefficient of specific growth rate $(\mu)$, accounting for 0.0618 , was determined for $G$. oxydans cells grown in the culture medium without glycerol addition (Table 1). Results of determinations provided in Table 1 indicate that the initial glycerol concentration in the medium had a greater impact on the growth of $G$. oxydans cells than the active acidity. Regardless of medium $\mathrm{pH}$, values of $\mu$ coefficient were the lowest in the cultures enriched with glycerol doses of 30 or $100 \mathrm{~g} \mathrm{~L}^{-1}$ (Table 1). The growth of G. oxydans strain in the medium with $\mathrm{pH} 5.0$ and glycerol concentration of $30 \mathrm{~g} \mathrm{~L}^{-1}$ was characterized by twofold elongation of the lag phase $(10 \mathrm{~h})$ compared to the growth of this strain in the control medium. In most variants of this experiment, the increase in the initial glycerol concentration resulted in elongation of both the lag and the log phase of growth (Table 1). Glycerol concentration ensuring the fastest cellular divisions of $G$. oxydans bacteria reached $70 \mathrm{~g} \mathrm{~L}^{-1}$ in the medium with $\mathrm{pH}$ 7.0 , which was proved by the highest value of $\mu$ coefficient, i.e., $\mu=0.0566$ (Table 1). In contrast, the lowest value of this coefficient $(\mu=0.0550)$ was determined in the medium with $\mathrm{pH} 5.0$ and initial substrate concentration at $50 \mathrm{~g} \mathrm{~L}^{-1}$. Analyses conducted in this stage of the study show also that bacteria of the species $G$. oxydans are capable to grow at both $\mathrm{pH}$ 5.0, which was earlier confirmed in ample research works [11,31], and at $\mathrm{pH} 7.0$.

Effect of DHA concentration on the growth of G. oxydans ATCC 621 bacteria

The next stage of the study was aimed at determining the effect of various concentrations of DHA on the growth of G. oxydans ATCC 621 strain bacteria. Based on the results of earlier analyses (Figs. 1, 2, 3) and the literature data [31], the active acidity of culture media at this stage of the study ( $\mathrm{pH}$ 5.0) was found optimal for the growth of acetic acid bacteria.
The achieved OD values allowed calculating the coefficient of the specific growth rate of $G$. oxydans cells $(\mu)$ and determining the length of the lag and log phases. Respective results were presented in Table 2.

Changes in OD values of the suspension of G. oxydans cells in the experimental media with different DHA contents were presented in Figs. 4, 5, and 6.

The study demonstrates that the growth of G. oxydans bacteria at low DHA concentrations $\left(10,20\right.$, or $\left.30 \mathrm{~g} \mathrm{~L}^{-1}\right)$ was similar to the cell growth of this strain in the control medium without DHA addition (Fig. 4). The adaptation phase lasted $5 \mathrm{~h}$ (Table 1), whereas the logarithmic phase lasted 10 (in the control medium and in the experimental medium with DHA addition at $10 \mathrm{~g} \mathrm{~L}^{-1}$ ) or $20 \mathrm{~h}$ (in the media with DHA doses of 20 or $30 \mathrm{~g} \mathrm{~L}^{-1}$ ), and the highest OD value reached 0.3 on average (Table 2). The highest coefficient of specific growth rate accounted for 0.0618 in the control medium and for 0.0413 in the experimental medium with DHA concentration of $10 \mathrm{~g} \mathrm{~L}^{-1}$ (Table 2).

Differences in OD values of particular cultures became noticeable when the initial concentration of DHA in the experimental medium reached $40 \mathrm{~g} \mathrm{~L}^{-1}$ (Fig. 4). In this variant, the OD of the culture at the final phase of logarithmic growth was 0.270 . In the same time, OD assayed for cultures grown in the media with DHA content of 10, 20, or $30 \mathrm{~g} \mathrm{~L}^{-1}$ reached 0.29 on average (Fig. 4). The value of specific growth rate coefficient in the media with DHA addition at 20 or $30 \mathrm{~g} \mathrm{~L}^{-1}$ reached 0.0231 and 0.0225 , respectively (Table 2). In the experimental media with DHA doses from 40 to $70 \mathrm{~g} \mathrm{~L}^{-1}$, the highest value of specific growth rate accounted for 0.0150 (at DHA concentration of $60 \mathrm{~g} \mathrm{~L}^{-1}$ ) and the lowest one for 0.0100 (at DHA concentration of $70 \mathrm{~g} \mathrm{~L}^{-1}$, Table 2).

The increasing dose of DHA in the culture media (55, $60,65,70 \mathrm{~g} \mathrm{~L}^{-1}$ ) was accompanied by decreasing values of OD of the cell suspension $(0.250,0.243,0.218$, and 0.174, respectively) (Fig. 5). These observations confirm
Table 2 Effect of DHA addition in the experimental media on the coefficient of specific rate growth $(\mu)$, length of lag phase, length of log phase, and the highest OD value

\begin{tabular}{llllll}
\hline DHA concentration $\left(\mathrm{g} \mathrm{L}^{-1}\right) \mu\left(\mathrm{h}^{-1}\right)$ & $\begin{array}{l}\text { Length of lag } \\
\text { phase }(\mathrm{h})\end{array}$ & $\begin{array}{l}\text { Length of log } \\
\text { phase }(\mathrm{h})\end{array}$ & \multicolumn{2}{l}{$\begin{array}{l}\text { Initial OD in log Final OD in } \\
\text { phase }\end{array}$} & \begin{tabular}{l} 
log phase \\
\hline Control medium
\end{tabular} \\
\hline 0.0618 & 5 & 10 & 0.208 & 0.385 \\
10 & 0.0413 & 5 & 10 & 0.198 & 0.297 \\
20 & 0.0231 & 5 & 20 & 0.188 & 0.299 \\
30 & 0.0225 & 5 & 20 & 0.182 & 0.285 \\
40 & 0.0102 & 10 & 25 & 0.209 & 0.270 \\
50 & 0.0113 & 15 & 20 & 0.190 & 0.250 \\
55 & 0.0127 & 10 & 25 & 0.182 & 0.250 \\
60 & 0.0150 & 10 & 20 & 0.180 & 0.243 \\
65 & 0.0110 & 10 & 25 & 0.165 & 0.218 \\
70 & 0.0100 & 10 & 20 & 0.158 & 0.174 \\
$75,80,85,90,95,100$ & No growth & & & \\
\hline
\end{tabular}


Fig. 4 Changes in the optical density of G. oxydans cells culture in control and experimental media with DHA $(10,20,30$, $40 \mathrm{~g} \mathrm{~L}^{-1}$ )
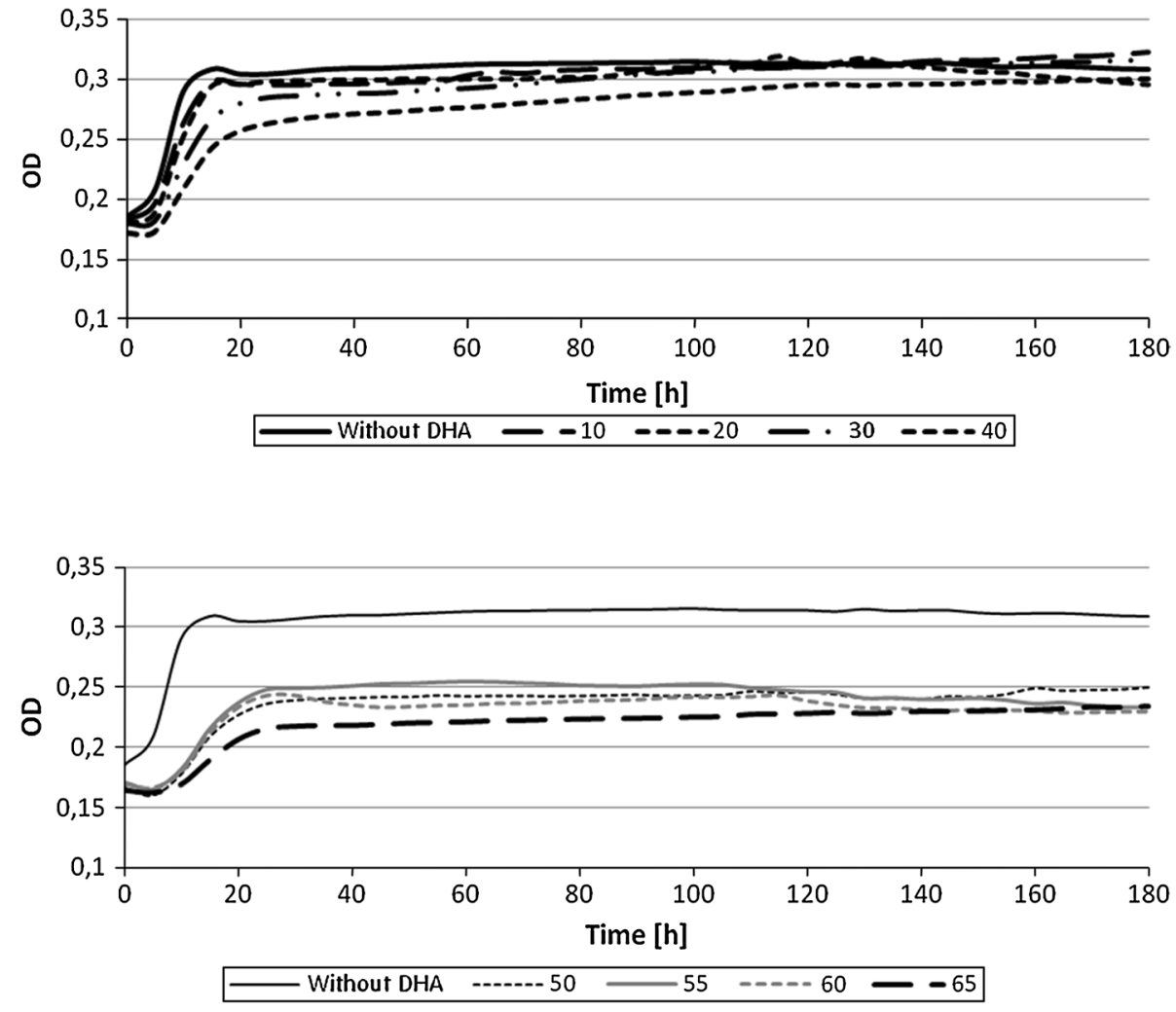

Fig. 5 Changes in the optical density of G. oxydans cells culture in control and experimental media with DHA $(50,55,60$, $65 \mathrm{~g} \mathrm{~L}^{-1}$ )

Fig. 6 Changes in the optical density of $G$. oxydans cells culture in control and experimental media with DHA $(70,75,80$, $\left.85,90,95,100 \mathrm{~g} \mathrm{~L}^{-1}\right)$

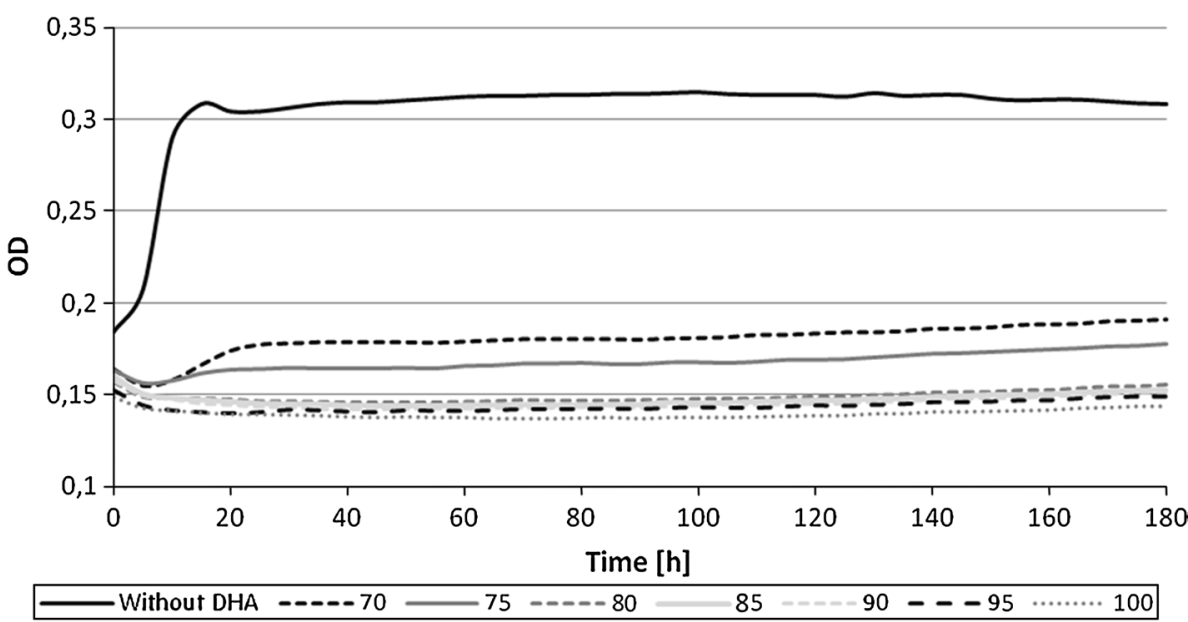

earlier findings [7, 23], according to which the capability of $G$. oxydans cells for divisions diminishes along with an increasing initial concentration of DHA in the culture medium.

Dihydroxyacetone (DHA) concentration exceeding $30 \mathrm{~g} \mathrm{~L}^{-1}$ resulted in elongation of the adaptation phase of G. oxydans cells to environmental conditions (compared to the control medium) (Table 2). The coefficient of specific growth rate $\mu$ in the experimental media containing higher than $30 \mathrm{~g} \mathrm{~L}^{-1}$ addition of DHA was about fivefold lower than in the control medium (Table 2).
Figure 6 depicts changes in OD values of G. oxydans cultures in the experimental media with DHA addition at 70 , $75,80,85,90,95$, or $100 \mathrm{~g} \mathrm{~L}^{-1}$. The presented results show explicitly that the growth of $G$. oxydans bacteria was inhibited at DHA concentrations exceeding $70 \mathrm{~g} \mathrm{~L}^{-1}$ (Fig. 6).

The increasing concentration of DHA in the culture medium was accompanied by a slower increase in OD values (Figs. 4, 5, 6), which probably indicated the arrestment of cell divisions. Similar conclusions were formulated by Claret et al. [7]. Literature data [36] show that the reaction of glycerol oxidation to DHA was significantly impaired 
at product concentration of $85 \mathrm{~g} \mathrm{~L}^{-1}$. The growth of acetic acid bacteria was inhibited when the content of resultant DHA in the medium exceeded $67 \mathrm{~g} \mathrm{~L}^{-1}$. This concentration of the product in the reaction medium induced irreversible destruction of cells of acetic acid bacteria. This could be due to the inhibiting effect of DHA on the activity of enzymes of the pentose cycle [4, 6, 25].

In the reported experiment, the lowest value of the specific growth rate $\mu(\mu=0.0100)$ was noted for cells grown on the medium with DHA addition of $70 \mathrm{~g} \mathrm{~L}^{-1}$ (Table 2). The study demonstrates, therefore, that even low doses of DHA present in the culture medium $\left(20,30 \mathrm{~g} \mathrm{~L}^{-1}\right)$ had a negative impact on the growth of $G$. oxydans strain and that doses exceeding $70 \mathrm{~g} \mathrm{~L}^{-1}$ completely arrested the growth of these bacteria.

\section{Conclusions}

The main drawback of the biotechnological production of DHA via glycerol oxidation by acetic acid bacteria of the G. oxydans species is process inhibition by substrate and/or product. The improper initial concentration of the substrate and increasing concentration of the product may inhibit the metabolic activity of bacterial cells.

Glycerol concentration that enabled rapid cell divisions of $G$. oxydans at $\mathrm{pH} 5.0$ reached $50 \mathrm{~g} \mathrm{~L}^{-1}$. In turn, in the culture medium with $\mathrm{pH} 7.0$, the highest specific growth rate of cells was determined at glycerol concentration of $70 \mathrm{~g} \mathrm{~L}^{-1}$, whereas in the medium with $\mathrm{pH} 8.0$, the highest specific growth rate of cells was determined at glycerol concentration of $50 \mathrm{~g} \mathrm{~L}^{-1}$. It was demonstrated that DHA had an inhibiting effect on the metabolic activity of $G$. oxydans bacteria even at low concentrations $\left(20-30 \mathrm{~g} \mathrm{~L}^{-1)}\right.$, and that above $70 \mathrm{~g} \mathrm{~L}^{-1}$, it made cell divisions impossible.

The presented results show explicitly that product concentration which inhibited the metabolic activity of $G$. oxydans cells reached $30 \mathrm{~g} \mathrm{~L}^{-1}$.

Based on the results achieved in the study, it may be concluded that the culture medium for efficient glycerol biotransformation of DHA could contain substrate in the concentration of $30 \mathrm{~g} \mathrm{~L}^{-1}$ and, simultaneously, exhibit active acidity stabilizing GlyDH (pH 8.0). Product concentration obtained under these conditions, i.e., $20-30 \mathrm{~g} \mathrm{~L}^{-1}$, will not inhibit the metabolic activity of the analyzed $G$. oxydans strain.

Conflict of interest The authors declare that they have no conflict of interest.

Compliance with Ethics Requirements This article does not contain any studies with human or animal subjects.

Open Access This article is distributed under the terms of the Creative Commons Attribution License which permits any use, distribution, and reproduction in any medium, provided the original author(s) and the source are credited.

\section{References}

1. Adachi O, Matsushita K (1997) USA Patent nr 56143774

2. Ameyama M, Shinagawa E, Matasushita K, Adachi O (1985) Agric Biol Chem 49:1001-1010

3. Bańkowski E (2004) Biochemistry, 1st edn. Elsevier Urban \& Partner,Wrocław

4. Bauer R, Katsikis N, Varga S, Hekmat D (2005) Bioprocess Biosyst Eng 5:37-43

5. Bories A, Claret C, Soucaille P (1991) Process Biochem 26:243-248

6. Claret C, Bories A, Soucaille P (1992) Curr Microbiol 25:149-155

7. Claret C, Salmon JM, Romieu C, Bories A (1994) Appl Microbiol Biotechnol 41:359-365

8. Cummings TF (2004) Occup Med 54:82-85

9. De Muynck C, Pereira SSC, Naessens M, Soetaert W, Vandamme EJ (2007) Crit Rev Biotechnol 27:147-171

10. Djuranovic SP, Kun JFJ, Schultz JE, Beitz E (2006) Biochem Biophys Acta 1758:1012-1017

11. Du Toit M, Pretorius IS (2000) S Afr J Enol Vitic 21:74-96

12. Erni B, Siebold C, Christen S, Srinivas A, Oberholzer A, Baumann U (2006) Cell Mol Life Sci 63:890-900

13. Gätgens C, Degner U, Bringer-Meyer S, Herrmann U (2007) Appl Microbiol Biotechnol 76:553-559

14. Green SR, Whalen EA, Molokie E (2004) J Biochem Microbiol Technol 3:351-355

15. Habe H, Fukuoka T, Morita T, Kitamoto D, Yakushi T, Matsushita K, Sakaki K (2010) Biosci Biotechnol Biochem 74:1391-1395

16. Hekmat D, Bauer R, Fricke J (2003) Bioproc Biosyst Eng 26:109-113

17. Henderson PW, Kadouch D, Singh SP, Zawaneh PN, Weiser J, Yazdi S, Weinstein A, Krotscheck U, Wechsler B, Putnam D, Spector JAJ (2010) Biomed Mater Res A 93:776-782

18. Holst O, Lundbäck H, Mattiasson B (1985) Appl Microbiol Biotechnol 22:383-388

19. Hu ZC, Liu ZQ, Xu JM, Zheng YG, Shen YC (2012) Prep Biochem Biotechnol 42:15-28

20. $\mathrm{Hu}$ ZC, Zheng YG (2011) Appl Biochem Biotechnol 165:1152-1160

21. Lapenaite I, Kurtinaitiene B, Razumiene J, Laurinavicius V, Marcinkeviciene L, Bachmatova I, Meskys R, Ramanavicius A (2005) Anal Chem Acta 549:140-150

22. Li M, Wu J, Liu X, Lin J, Wei D, Chen H (2010) Biores Technol 101:8294-8299

23. Ma L, Lu W, Xia Z, Wen J (2010) Biochem Eng J 49:61-67

24. Mamlouk D, Gullo M (2013) Indian J Microbiol 53:377-384

25. Mishra R, Jain SR, Kumar A (2008) Biotechnol Adv 26:293-303

26. Nabe K, Izuo N, Yamada S, Chibata I (1979) Appl Environ Microbiol 38:1056-1060

27. Obeid OA, Jamal ZM, Hwalla N, Emery PW (2006) Nutrition 22:794-801

28. Omar A, Bittar S, Hwalla N (2005) Nutrition 21:224-229

29. Peters B, Mientus M, Kostner D, Junker A, Liebl W, Ehrenreich A (2013) Appl Microbiol Biotechnol 14:6397-6412

30. Schmid D, Belser E, Zulli F (2007) Cosmet Toilet 6:55-60

31. Sievers M, Swings J (2005) Bergey's manual of systematic bacteriology. In: Garrity GM (ed) vol 2 Springer NY 41-79

32. Sochocka M, Boratyński J (2011) Post Hig Med Dośw 65:714-724 
33. Stanko RT, Diven WF, Robertson RJ, Spina RJ, Galbreath RW, Reilly JJ, Goss FL (1993) J Sports Sci 11:17-23

34. Stasiak-Różańska L, Błażejak S (2012) Eur Food Res Technol 235:1125-1132

35. Svitel J, Sturdik E (1994) J Ferment Technol 78:351-355

36. Tkáč J, Navrátil M, Šturdík E, Gemeiner P (2001) Enz Microbiol Technol 28:383-388

37. Uzcategui NL, Carmona-Gutierrez D, Denninger V, Schoenfeld C, Lang F, Figarella K, Duszenko M (2007) Antimicrob Agents Chemother 51:3960-3968
38. Wethmar M, Deckwer WD (1999) Biotechnol Tech 13:283-287

39. Wilson JJ, Khachatourians GG, Ingledew WM (1982) Biotechnol Lett 4:333-338

40. Xu X, Chen X, Jin M, Wu X, Wang X (2009) Chin J Biotechnol 25:903-908 